\title{
Risk prediction models for colorectal cancer in people with symptoms: a systematic review
}

Tom G. S. Williams ${ }^{1}$, Joaquín Cubiella ${ }^{2}$, Simon J. Griffin ${ }^{3}$, Fiona M. Walter ${ }^{3}$ and Juliet A. Usher-Smith ${ }^{3 *}$

\begin{abstract}
Background: Colorectal cancer (CRC) is the fourth leading cause of cancer-related death in Europe and the United States. Detecting the disease at an early stage improves outcomes. Risk prediction models which combine multiple risk factors and symptoms have the potential to improve timely diagnosis. The aim of this review is to systematically identify and compare the performance of models that predict the risk of primary CRC among symptomatic individuals.

Methods: We searched Medline and EMBASE to identify primary research studies reporting, validating or assessing the impact of models. For inclusion, models needed to assess a combination of risk factors that included symptoms, present data on model performance, and be applicable to the general population. Screening of studies for inclusion and data extraction were completed independently by at least two researchers.
\end{abstract}

Results: Twelve thousand eight hundred eight papers were identified from the literature search and three through citation searching. 18 papers describing 15 risk models were included. Nine were developed in primary care populations and six in secondary care. Four had good discrimination (AUROC > 0.8) in external validation studies, and sensitivity and specificity ranged from 0.25 and 0.99 to 0.99 and 0.46 depending on the cut-off chosen.

Conclusions: Models with good discrimination have been developed in both primary and secondary care populations. Most contain variables that are easily obtainable in a single consultation, but further research is needed to assess clinical utility before they are incorporated into practice.

Keywords: Colorectal cancer, Risk, Model, Symptoms, Prediction

\section{Background}

Colorectal cancer (CRC) is the third most common cancer worldwide and the fourth leading cause of cancer-related death [1]. Detecting the disease at an early stage improves outcomes [2]. Whilst screening has been successful in reducing the incidence and mortality of CRC by increasing the proportion diagnosed at an early stage and facilitating removal of pre-neoplastic lesions [3-5], the majority of cancers are still diagnosed after symptomatic presentation [6]. Three previous meta-analyses have shown that individual symptoms, such as rectal bleeding and change in

\footnotetext{
* Correspondence: jau20@medschl.cam.ac.uk

${ }^{3}$ The Primary Care Unit, Department of Public Health and Primary Care,

University of Cambridge, Cambridge CB1 8RN, UK

Full list of author information is available at the end of the article
}

bowel habit, are associated with $\mathrm{CRC}$, but are also common in populations without cancer and so have poor sensitivity for CRC [7-9]. Consequently, identifying which patients from primary care should be referred for diagnostic investigation remains challenging.

Several approaches have been developed to improve the appropriateness of referrals for investigation of symptoms suggestive of CRC and reduce delays in diagnosis. The NHS in England introduced the two-week wait (2WW) referral system in 2000 , followed by the NICE suspected cancer referral guidelines in 2005 which have been recently updated [10]. A number of evaluations have shown that the $2 \mathrm{WW}$ referral system for suspected CRC has variable sensitivity and low specificity and does not improve diagnostic accuracy $[9,11-16]$. In 
recent years, several predictive models have been developed to identify people at higher risk of CRC among those with symptoms. These have the potential to improve the consistency and quality of clinical decisionmaking. However, their strengths, weaknesses and relative performance are uncertain, and few direct comparisons have been made. The aim of this review was to systematically identify and compare the performance of models that predict the risk of undiagnosed prevalent primary CRC for symptomatic individuals.

\section{Methods}

We performed a systematic literature review following an a priori established study protocol (available on request) that followed the PRISMA guidelines (see Additional file 1 for the PRISMA checklist).

\section{Search strategy}

We used a combination of subject headings including 'colorectal cancer', 'risk/risk factor/risk assessment/chance' and 'prediction/model/score' to conduct an electronic literature search within Medline and EMBASE. The search period ran from January 2000 to March 2014 (see Additional file 2 for the complete search strategy for Medline and EMBASE). We subsequently hand searched the reference lists of all included papers. We also considered for inclusion papers published before 2000 describing the development of models that were validated in included papers.

\section{Study selection}

To be included, studies had to be published as a primary research paper in a peer-reviewed journal and either describe, validate or assess the impact of a risk model that allowed identification of people at higher risk of CRC or CRC and advanced colorectal neoplasia. The risk model had to feature two or more risk factors, including symptoms, for prevalent undiagnosed colorectal cancer at the level of the individual. In addition, a quantitative measure of model performance was required. Conference proceedings, papers not in English, and studies of a specific patient group, for example immunosuppressed patients or patients with a past history of CRC, were excluded.

One reviewer (JUS) screened the titles and abstracts of papers identified by the Medline and EMBASE searches to exclude studies that were clearly not relevant. A second reviewer (TGSW) independently assessed a random selection of $10 \%$ of the papers at title and abstract level and both reviewers (TGSW and JUS) independently assessed all the full text of papers if a definite decision to reject could not be made based on title and abstract alone. All reviewers met to discuss discrepancies and reach a consensus decision on inclusion or exclusion.

\section{Data extraction and synthesis}

Two reviewers (TGSW and JC) extracted data from each paper using a standardised form. Discrepancies were examined and resolved by a third reviewer (JUS). We extracted information on the components of each risk model and potential sources of bias. These included: study design and participants; methods of model development; and variables included in the risk model. The methods of studies published for each risk model was also classified according to the TRIPOD guidelines (1a-Development only; $1 \mathrm{~b}$-Development and validation using resampling; 2a-Random split-sample development and validation; 2b-Non-random split-sample development and validation; 3-Development and validation using separate data; 4-Validation study) [17]. Where multiple models were described within the same study, each model was included separately.

Reported measures of discrimination (area under the receiver operating characteristic curve (AUROC)), accuracy (sensitivity and specificity), calibration and utility were used to compare the performance of different risk models and thresholds in development and validation populations. Numerical values for the AUROC were used to compare discrimination and the sensitivity and specificity to compare the accuracy, of different models and thresholds. For those papers in which sensitivity and specificity were not reported explicitly, where possible we calculated the values from data provided in the paper. Figures were produced using RevMan version 5.3 and where multiple studies reported the sensitivity and specificity of the same model at the same threshold, the combined values were calculated using Meta-DiSc version 1.4.

\section{Quality assessment}

Quality assessment was performed at the same time as data extraction. Since our review included studies with different designs we used a checklist based on the Critical Appraisal Skills Programme guidelines for case-control and cohort studies [18] as an initial framework, and then classified each study as high, medium or low quality. No studies were excluded based on quality assessment alone.

\section{Results \\ Included studies}

After duplicates were removed, the search identified 12,808 papers of which 12,765 were excluded at title and abstract level. A further 29 were excluded after full-text assessment by at least two reviewers (TGSW and JUS). There was complete agreement among researchers throughout the screening process. The most common reasons for exclusion were that the papers did not report a statistical measure of model performance $(n=9)$, only evaluated one predictor $(n=6)$, or were conference abstracts 
$(n=4)$. Three additional papers were identified through citation searching, including one published prior to 2000 which was included as it had been externally validated in one of the papers identified through the literature search. In total we included 18 papers describing 15 risk prediction models in the review (Fig. 1). Only one paper assessed the impact of one of the models in practice [19].

A summary of the quality assessment of each of the 18 papers is given in Table 1. Eleven were assessed as high quality, four as medium quality and three as low quality. The studies assessed as low quality were two cross-sectional studies recruiting patients presenting to either primary or secondary care with rectal bleeding $[20,21]$, and the single study assessing model impact [19].

\section{Risk model development and validation}

Table 1 also summarizes the methods used to develop and validate the models. Of the 15 included models, nine were developed in primary care populations [21-27] and six in secondary care $[20,28-32]$. Most $(n=11)$ had $\mathrm{CRC}$ as a single outcome, whilst two in secondary care predicted CRC combined with advanced adenoma (a polyp measuring $10 \mathrm{~mm}$ or bigger, or a polyp of any size with a villous histology [20]) or pre-malignant adenomas [28]. The remaining two reported $\mathrm{CRC}$ risk alongside the risk of cancers of several other sites [26, 27].

Most models were developed from either cross sectional $(n=6)$, prospective cohort $(n=4)$ or casecontrol studies $(n=4)$, with one developed based on clinical experience [30]. Four used self-administered questionnaires or interviews conducted by nonmedically trained staff to gather information. The remaining 11 models required the input of a healthcare worker. Nine of the 15 models have been validated: one using bootstrap resampling [32]; two using a random split-sample [26, 27]; and six in external populations $[21,24,25,30]$. Details of the methods and study populations for the validation studies are also given in Table 1.

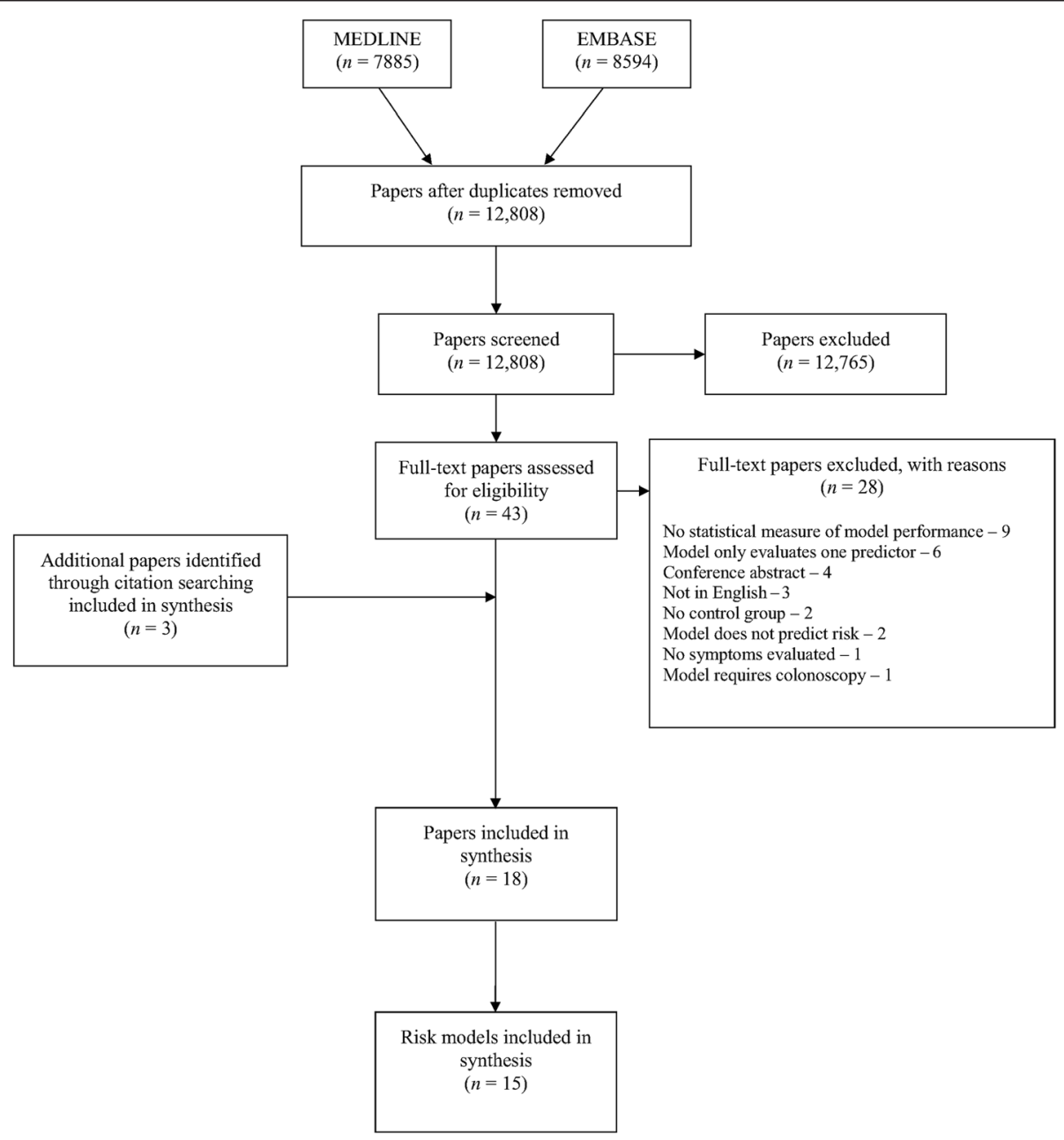

Fig. 1 PRISMA flow diagram 
Table 1 Summary of quality assessment and study design for the 18 included papers

\begin{tabular}{|c|c|c|c|c|c|c|c|c|c|c|}
\hline $\begin{array}{l}\text { Author, date, } \\
\text { country, setting }\end{array}$ & Quality $^{f}$ & Outcome & Data collection & $\begin{array}{l}\text { Selection of } \\
\text { variables }\end{array}$ & \multicolumn{2}{|c|}{$\begin{array}{l}\text { Identification of } \\
\text { study population }\end{array}$} & $\begin{array}{l}\text { Identification of } \\
\text { outcome cases }\end{array}$ & Exclusions & \multicolumn{2}{|c|}{ Study population } \\
\hline \multicolumn{11}{|c|}{ Model development; Case-control studies } \\
\hline & & & & & Cases & Controls & & & Cases & Controls \\
\hline $\begin{array}{l}\text { Hamilton, 2005, UK, } \\
\text { primary care [22] }\end{array}$ & M & CRC & $\begin{array}{l}\text { Primary care } \\
\text { records from } \\
21 \text { practices }\end{array}$ & $\begin{array}{l}\text { Occurring in } \\
\text { at least } 2.5 \% \\
\text { of cases or } \\
\text { controls }\end{array}$ & $\begin{array}{l}>40 \text { years } \\
\text { with } \\
\text { primary } \\
\text { CRC }\end{array}$ & $\begin{array}{l}5 \text { controls per case } \\
\text { matched for sex, } \\
\text { general practice } \\
\text { and age and alive } \\
\text { at point of case } \\
\text { diagnosis }\end{array}$ & $\begin{array}{l}\text { Cancer registry at } \\
\text { one hospital }\end{array}$ & $\begin{array}{l}\text { Unobtainable records, } \\
\text { no consultations in } \\
2 \text { years before diagnosis, } \\
\text { previous CRC, residence } \\
\text { outside Exeter at time } \\
\text { of diagnosis. }\end{array}$ & 349 & 1,744 \\
\hline $\begin{array}{l}\text { Hamilton, 2009, UK, } \\
\text { primary care [23] }\end{array}$ & M & CRC & THIN database & $\begin{array}{l}\text { Literature } \\
\text { review }\end{array}$ & $\begin{array}{l}>30 \text { years } \\
\text { with CRC }\end{array}$ & $\begin{array}{l}\text { Up to } 7 \text { controls } \\
\text { without CRC } \\
\text { matched for practice, } \\
\text { sex and age }\end{array}$ & $\begin{array}{l}\text { Diagnosis of CRC } \\
\text { within study } \\
\text { period }\end{array}$ & $\begin{array}{l}<2 \text { years of full electronic } \\
\text { records before date of } \\
\text { case diagnosis. }\end{array}$ & 5,477 & 38,314 \\
\hline \multicolumn{11}{|c|}{ Model development and external validation; Case-control study } \\
\hline & & & & & Cases & Controls & & & Cases & Controls \\
\hline \multirow{4}{*}{$\begin{array}{l}\text { Marshall, 2011, UK, } \\
\text { primary care [24] }\end{array}$} & $\mathrm{H}$ & CRC & \multicolumn{8}{|c|}{ BB equation development and CAPER Score external validation } \\
\hline & & & \multicolumn{5}{|c|}{ See Hamilton, 2009 [23] } & $\begin{array}{l}\text { As in Hamilton, } 2009 \text { plus } \\
\text { patients with severe } \\
\text { anaemia }(H \mathrm{Hb}<10 \mathrm{~g} / \mathrm{dl}) \text {, } \\
\text { rectal bleeding, abnormal } \\
\text { rectal examination or } \\
\text { positive FOBT, or without } \\
\text { any of abdominal pain, } \\
\text { weight loss, diarrhoea or } \\
\text { constipation }\end{array}$ & 117 & 433 \\
\hline & & CRC & \multicolumn{8}{|c|}{ CAPER Score development and BB equation external validation } \\
\hline & & & \multicolumn{5}{|c|}{ See Hamilton, 2005 [22] } & & & \\
\hline \multicolumn{11}{|c|}{ Model development and random split-sample internal validation; Cohort studies } \\
\hline & & & & & & & & & Included & $\begin{array}{l}\text { Cases } \\
\text { (\% of } \\
\text { included) }\end{array}$ \\
\hline \multirow{6}{*}{$\begin{array}{l}\text { Hippisley-Cox, 2012, } \\
\text { UK, primary care } \\
\text { (QCancer } \\
\text { (colon)) }[25]\end{array}$} & \multirow[t]{6}{*}{$\mathrm{H}$} & \multirow[t]{6}{*}{ CRC } & \multirow{6}{*}{$\begin{array}{l}\text { QResearch } \\
\text { database }\end{array}$} & \multirow{6}{*}{$\begin{array}{l}\text { 'Established } \\
\text { predictor } \\
\text { variables' and } \\
\text { red flag } \\
\text { symptoms }\end{array}$} & \multirow{6}{*}{\multicolumn{2}{|c|}{$\begin{array}{l}30-84 \text { year-old patients } \\
\text { registered with practices } \\
\text { between } 1 / 1 / 2000 \text { and } \\
30 / 09 / 2010 \text { and without } \\
\text { CRC }\end{array}$}} & \multirow{6}{*}{$\begin{array}{l}\text { Incident cancer } \\
\text { diagnosis in the } \\
2 \text { years after cohort } \\
\text { entry recorded in } \\
\text { GP records or ONS } \\
\text { cause-of-death } \\
\text { record }\end{array}$} & \multirow{6}{*}{$\begin{array}{l}\text { History of CRC, recorded } \\
\text { red flag symptom }{ }^{f} \text { in the } \\
12 \text { months preceding } \\
\text { the study date, or missing } \\
\text { Townsend deprivation } \\
\text { score. }\end{array}$} & \multicolumn{2}{|l|}{ Development } \\
\hline & & & & & & & & & $F: 1,172,670$ & $\begin{array}{l}F: 4,798 \\
(0.2 \%)\end{array}$ \\
\hline & & & & & & & & & $M: 1,178,382$ & $\begin{array}{l}\text { M:4,798 } \\
(0.2 \%)\end{array}$ \\
\hline & & & & & & & & & \multicolumn{2}{|c|}{ Internal validation } \\
\hline & & & & & & & & & $F: 616,361$ & $\begin{array}{l}F: 2603 \\
(0.2 \%)\end{array}$ \\
\hline & & & & & & & & & M: 620,240 & $\begin{array}{l}M: 2603 \\
(0.2 \%)\end{array}$ \\
\hline
\end{tabular}


Table 1 Summary of quality assessment and study design for the 18 included papers (Continued)

\begin{tabular}{|c|c|c|c|c|c|c|c|c|c|}
\hline \multirow{4}{*}{$\begin{array}{l}\text { Hippisley-Cox, } 2013 \\
\text { (female), UK, primary care } \\
\text { (QCancer }{ }^{\oplus} \text { (combined)) [26] }\end{array}$} & \multirow[t]{4}{*}{$\mathrm{H}$} & \multirow{4}{*}{$\begin{array}{l}\text { CRC and } 11 \\
\text { other cancers }\end{array}$} & \multirow{4}{*}{$\begin{array}{l}\text { QResearch } \\
\text { database }\end{array}$} & \multirow{4}{*}{$\begin{array}{l}\text { Previous study, } \\
\text { and literature } \\
\text { review }\end{array}$} & \multirow{4}{*}{$\begin{array}{l}25-89 \text { year-old } \\
\text { patients registered } \\
\text { with practices } \\
\text { between } 1 / 1 / 2000 \\
\text { and } 1 / 04 / 2012 \text { and } \\
\text { without CRC }\end{array}$} & \multirow{4}{*}{$\begin{array}{l}\text { Incident cancer } \\
\text { diagnosis in the } \\
2 \text { years after cohort } \\
\text { entry recorded in } \\
\text { GP records or ONS } \\
\text { cause-of-death } \\
\text { record }\end{array}$} & \multirow{4}{*}{$\begin{array}{l}\text { Recorded red flag } \\
\text { symptom in the } 12 \\
\text { months before the } \\
\text { study entry date, or } \\
\text { missing Townsend } \\
\text { deprivation score. }\end{array}$} & \multicolumn{2}{|c|}{ Development } \\
\hline & & & & & & & & $1,240,864$ & $\begin{array}{l}2607 \\
(0.18 \%)\end{array}$ \\
\hline & & & & & & & & \multicolumn{2}{|c|}{ Internal validation } \\
\hline & & & & & & & & 679,174 & $\begin{array}{l}1725 \\
(0.25 \%)\end{array}$ \\
\hline \multirow{4}{*}{$\begin{array}{l}\text { Hippisley-Cox, } 2013 \text { (male), UK, } \\
\text { primary care } \\
\text { (QCancer }{ }^{\oplus} \text { (combined)) [27] }\end{array}$} & \multirow{4}{*}{ H } & \multirow{4}{*}{$\begin{array}{l}\mathrm{CRC} \text { and } 9 \text { other } \\
\text { cancers }^{\mathrm{b}}\end{array}$} & \multirow{4}{*}{$\begin{array}{l}\text { QResearch } \\
\text { database }\end{array}$} & \multirow{6}{*}{$\begin{array}{l}\text { Previous study, } \\
\text { and literature } \\
\text { review }\end{array}$} & \multirow{6}{*}{$\begin{array}{l}25-89 \text { year-old } \\
\text { patients registered } \\
\text { with practices } \\
\text { between } 1 / 1 / 2000 \\
\text { and } 1 / 04 / 2012 \text { and } \\
\text { without CRC }\end{array}$} & \multirow{6}{*}{$\begin{array}{l}\text { Incident cancer } \\
\text { diagnosis in the } \\
2 \text { years after cohort } \\
\text { entry recorded in } \\
\text { GP records or ONS } \\
\text { cause-of-death } \\
\text { record }\end{array}$} & \multirow{6}{*}{$\begin{array}{l}\text { Recorded red flag } \\
\text { symptom in the } 12 \\
\text { months before the } \\
\text { study entry date, or } \\
\text { missing Townsend } \\
\text { deprivation score. }\end{array}$} & \multicolumn{2}{|c|}{ Development } \\
\hline & & & & & & & & $1,263,071$ & $\begin{array}{l}3250 \\
(0.26 \%)\end{array}$ \\
\hline & & & & & & & & \multicolumn{2}{|c|}{ Internal validation } \\
\hline & & & & & & & & 667,603 & $\begin{array}{l}1356 \\
(0.2 \%)\end{array}$ \\
\hline \multicolumn{6}{|c|}{ Model development; Cross-sectional studies } & & & & \\
\hline & & & & & & & & Included & $\begin{array}{l}\text { Cases } \\
\text { (\% of } \\
\text { included) }\end{array}$ \\
\hline $\begin{array}{l}\text { Adelstein, 2010, Australia, } \\
\text { secondary care [32] }\end{array}$ & $\mathrm{H}$ & CRC & $\begin{array}{l}\text { Self-administered } \\
\text { questionnaire }\end{array}$ & Not reported & $\begin{array}{l}\text { Patients }>18 \text { years } \\
\text { old scheduled for } \\
\text { colonoscopy at } \\
\text { hospitals }\end{array}$ & $\begin{array}{l}\text { Complete } \\
\text { colonoscopy } \\
\text { and histology }\end{array}$ & $\begin{array}{l}\text { Completion of } \\
\text { questionnaire } \\
>6 \text { months before } \\
\text { colonoscopy, advanced } \\
\text { adenomac, incomplete } \\
\text { colon evaluation }\end{array}$ & 7,736 & $\begin{array}{l}159 \\
(2.1 \%)\end{array}$ \\
\hline $\begin{array}{l}\text { Adelstein, 2011, Australia, } \\
\text { secondary care [31] }\end{array}$ & $\mathrm{H}$ & CRC & $\begin{array}{l}\text { See Adelstein } \\
2010[32]\end{array}$ & & & & $\begin{array}{l}\text { Completion of } \\
\text { questionnaire } \\
>6 \text { months before } \\
\text { colonoscopy, adenoma }{ }^{d} \text {, } \\
\text { incomplete colon } \\
\text { evaluation }\end{array}$ & 6943 & $\begin{array}{l}159 \\
(2.3 \%)\end{array}$ \\
\hline $\begin{array}{l}\text { Fijten, 1995, Netherlands, } \\
\text { primary care [21] }\end{array}$ & $\mathrm{L}$ & CRC & $\begin{array}{l}\text { Patient and doctor } \\
\text { questionnaires, and } \\
\text { blood sample }\end{array}$ & $\begin{array}{l}\text { Literature } \\
\text { review }\end{array}$ & $\begin{array}{l}\text { Patients presenting } \\
\text { to } 83 \mathrm{GP} \text { practices } \\
\text { with overt rectal } \\
\text { bleeding or a } \\
\text { history of visible } \\
\text { rectal blood loss in } \\
\text { previous } 3 \text { months. }\end{array}$ & $\begin{array}{l}\text { Medical record } \\
\text { review coded } \\
\text { using the } \\
\text { International } \\
\text { Classification of } \\
\text { Primary Care } \\
\text { for diagnostic } \\
\text { classification }\end{array}$ & $\begin{array}{l}\text { Patients aged }<18 \text { or } \\
>75, \text { pregnancy, urgent } \\
\text { admission to hospital } \\
\text { or follow-up not } \\
\text { available. }\end{array}$ & 290 & 9 (3.4 \%) \\
\hline $\begin{array}{l}\text { Hurst, 2007, UK, secondary } \\
\text { care [28] }\end{array}$ & M & $\begin{array}{l}\text { CRC or pre- } \\
\text { malignant } \\
\text { adenomas }\end{array}$ & $\begin{array}{l}\text { Proforma-based } \\
\text { history, examination } \\
\text { and blood sample }\end{array}$ & Not reported & $\begin{array}{l}\text { All adult patients } \\
\text { referred to a } \\
\text { specialist colorectal } \\
\text { clinic }\end{array}$ & $\begin{array}{l}\text { Patients tracked } \\
\text { until a definitive } \\
\text { diagnosis was } \\
\text { reached }\end{array}$ & $\begin{array}{l}\text { Patients not further } \\
\text { investigated after } \\
\text { initial consultation } \\
\text { or who did not } \\
\text { attend follow up }\end{array}$ & 300 & $\begin{array}{l}95 \\
(31.7 \%)\end{array}$ \\
\hline
\end{tabular}


Table 1 Summary of quality assessment and study design for the 18 included papers (Continued)

\begin{tabular}{|c|c|c|c|c|c|}
\hline $\begin{array}{l}\text { Lam, 2002, Hong Kong, } \\
\text { secondary care [20] }\end{array}$ & $L$ & $\begin{array}{l}\text { CRC or significant } \\
\text { neoplasiae }\end{array}$ & $\begin{array}{l}\text { Questionnaire } \\
\text { conducted by } \\
\text { non-medically } \\
\text { trained interviewers }\end{array}$ & Not reported & $\begin{array}{l}\text { New patients } \\
\text { attending surgical } \\
\text { department for } \\
\text { rectal bleeding }\end{array}$ \\
\hline $\begin{array}{l}\text { Mahadavan, 2011, UK, } \\
\text { secondary care [29] }\end{array}$ & M & CRC & $\begin{array}{l}\text { Self-administered } \\
\text { questionnaire, } \\
\text { history, faecal, } \\
\text { blood and rectal } \\
\text { samples }\end{array}$ & Not reported & $\begin{array}{l}\text { All patients }>40 \\
\text { years referred to } \\
\text { a surgical clinic } \\
\text { via the } 2 w^{9} w^{9} \\
\text { system for } \\
\text { colorectal cancer }\end{array}$ \\
\hline
\end{tabular}

Model development and external validation; Cross-sectional study

colorectal cancer

\begin{tabular}{|c|c|c|c|c|c|}
\hline $\begin{array}{l}\text { Selvachandran, 2002, UK, } \\
\text { secondary care (WNS) } \\
\text { [30] }{ }^{\mathrm{h}}\end{array}$ & $\mathrm{H}$ & CRC & $\begin{array}{l}\text { Self-administerec } \\
\text { questionnaire }\end{array}$ & Not reported & $\begin{array}{l}\text { Patients referred } \\
\text { by GPs with } \\
\text { symptoms } \\
\text { suggestive of } \\
\text { distal colonic or }\end{array}$ \\
\hline
\end{tabular}

Model external validation; Cohort study

Model(s)

validated

Collins, 2012, UK,
primary care [33] $\quad$ H $\quad \begin{aligned} & \text { QCancer }{ }^{\oplus} \text { (colon) THIN database } \\ & \text { (female and } \\ & \text { male) }[25]\end{aligned}$

30-84 year-old

patients registered

with practices

between $1 / 1 / 2000$

and without CRC

diagnosis of $C R$

in the 2 years

after cohort entry

Patients with a history of $\mathrm{CRC}$, a recorded

red flag symptom

in the 12 months

date, registered

D, Gl cancer,

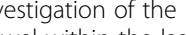

6 months or the last

Model external validation; Cross-sectional studies

Model(s)

Validated

$\begin{array}{llll}\begin{array}{l}\text { Ballal, 2009, UK, } \\ \text { secondary care [35] }\end{array} \quad H \quad \text { WNS [30] } & \begin{array}{l}\text { Self-administered } \\ \text { questionnaire }\end{array} & \text { N/A } & \begin{array}{l}\text { Patients with } \\ \text { colorectal } \\ \text { symptoms } \\ \text { referred by GPs }\end{array} \\ & & & \\ & & \end{array}$

date, registered

$<12$ months with

practice or w

$<12$ months with
practice or with
invalid dates

Male:

$1,059,765 \quad 2,036$

$$
\begin{aligned}
& 2,036 \\
& (0.19 \%)
\end{aligned}
$$

Included Cases

(\% of (\% of

eligible) included)

A combination of Patients thought (on

rigid sigmoidoscopy, the basis of the referral)

flexible sigmoidoscopy, most likely to have

$\begin{array}{ll}\text { flexible sigmoidoscopy, most likely to have } \\ \text { colonoscopy or } & \text { right-sided CRC, or but }\end{array}$

did not attend 
Table 1 Summary of quality assessment and study design for the 18 included papers (Continued)

\begin{tabular}{|c|c|c|c|c|c|c|c|c|c|}
\hline $\begin{array}{l}\text { Hodder, 2005, UK, } \\
\text { secondary care [34] }\end{array}$ & $\mathrm{H}$ & $\begin{array}{l}\text { WNS [30], Fijten } \\
1995 \text { [21] }\end{array}$ & $\begin{array}{l}\text { Self-administered } \\
\text { questionnaire }\end{array}$ & N/A & $\begin{array}{l}\text { Patients referred } \\
\text { from primary care } \\
\text { with colorectal } \\
\text { symptoms }\end{array}$ & $\begin{array}{l}\text { Secondary care } \\
\text { investigations - } \\
\text { minimum flexible } \\
\text { sigmoidoscopy }\end{array}$ & Not reported & 3,302 & $\begin{array}{l}156 \\
(4.7 \%)\end{array}$ \\
\hline $\begin{array}{l}\text { Rai, 2008, UK, secondary } \\
\text { care [11] }\end{array}$ & $\mathrm{H}$ & WNS [30] & $\begin{array}{l}\text { Self-administered } \\
\text { questionnaire }\end{array}$ & N/A & $\begin{array}{l}\text { GP referral with any } \\
\text { of: lower bowel- } \\
\text { related symptoms, } \\
\text { unexplained iron } \\
\text { deficiency anaemia, } \\
\text { positive FOBT, or } \\
\text { palpable rectal/ } \\
\text { abdominal mass }\end{array}$ & $\begin{array}{l}\text { Follow up during } \\
\text { course of hospital } \\
\text { investigations until } \\
\text { a final diagnosis } \\
\text { made }\end{array}$ & $\begin{array}{l}\text { Patients admitted } \\
\text { hospital as an } \\
\text { emergency and } \\
\text { subsequently } \\
\text { diagnosed with } \\
\text { CRC }\end{array}$ & 1,422 & $\begin{array}{l}83 \\
(5.84 \%)\end{array}$ \\
\hline \multicolumn{10}{|l|}{ Model utility; cohort study } \\
\hline & & Model used & & & & Outcome measures & & Included & Interviews \\
\hline $\begin{array}{l}\text { Hamilton, 2013, UK, } \\
\text { primary care [19] }\end{array}$ & $L$ & $\begin{array}{l}\text { Hamilton } 2005 \\
{[22]}\end{array}$ & $\begin{array}{l}\text { GP usage and } \\
\text { outcomes from } \\
\text { practices and } \\
\text { local trusts; } \\
\text { qualitative } \\
\text { interviews }\end{array}$ & Not reported & $\begin{array}{l}\text { Risk assessment } \\
\text { tools (RATs) supplied } \\
\text { to } 614 \text { GPs at } 164 \\
\text { practices for } 6 \text { months; } \\
\text { interviews with GP } \\
\text { cancer network leads } \\
\text { and sample of GP } \\
\text { users from practices } \\
\text { with differing patient } \\
\text { demographics. }\end{array}$ & $\begin{array}{l}\text { Number of 2WW } \\
\text { referrals and } \\
\text { colonoscopies for } \\
\text { patients >40; } \\
\text { symptoms used } \\
\text { in RATs; qualitative } \\
\text { interview data. }\end{array}$ & $\begin{array}{l}\text { RATs performed } \\
\text { on patients }<40 ; \\
\text { RATs that did not } \\
\text { identify the reported } \\
\text { symptoms. }\end{array}$ & 1433 & $\begin{array}{l}23 \mathrm{GP} \\
\text { responders }\end{array}$ \\
\hline
\end{tabular}

CRC colorectal cancer, ONS office of national statistics, FOBT faecal occult blood test, IBD Inflammatory bowel disease, Hb haemoglobin, WNS Weighted Numerical Score developed by Selvachandran 2002 [30], RAT risk assessment tool

aLung, gastro-oesophageal, pancreatic, renal tract, haematological, breast, ovarian, uterine, cervical and other cancer

'Lung, gastro-oesophageal, pancreatic, renal tract, haematological, prostate, testicular, and other cancer

cAdenoma with significant ( $>25 \%$ ) villous features, or high grade dysplasia, including carcinoma-in-situ, or size $10 \mathrm{~mm}$ or larger

Adenoma of any size or histology

Pelyp $10 \mathrm{~mm}$ or larger, or a polyp of any size with a villous histology

rectal bleeding, weight loss, abdominal pain, loss of appetite

$g_{2}$ WW - Two week wait

${ }^{n}$ The method of developing the WNS is copyrighted and incompletely reported 


\section{Variables included in the risk models}

We categorized risk factor variables into five types: demographic, personal and family medical history, symptoms, signs, and investigations (Table 2). Seventeen variables were included in three or more models: four demographic variables (age, sex, smoking, alcohol); family history of CRC; eight symptoms (rectal bleeding, change in bowel habit, diarrhoea, constipation, abdominal pain, weight loss, loss of appetite, mucous in the stool); abnormal rectal examination; and three investigations (haemoglobin, mean cell volume, faecal occult blood testing). All models included symptoms, four included only symptoms [22-24], and most also included age $(n=11)$ and sex $(n=9)$. The choice of variable in each model was often influenced by the study design. For example, the Hamilton et al. 2005 risk model [22] and the CAPER score [24] were developed from case-control studies using primary care records and include symptoms plus additional signs and investigations without any demographic information or personal or family medical history. In contrast, the models developed by Adelstein [31, 32] from patient-completed questionnaires include symptoms plus demographic information and personal or family medical history.

\section{Performance of risk models \\ Accuracy}

Sensitivity and specificity were reported for 11 of the 15 models in either development populations $(n=5)$, in random split-sample internal validation $(n=2)$, random split-sample internal validation and external populations $(n=2)$ or in external populations $(n=2)$; for four models these were provided for multiple thresholds. These values are summarized in Fig. 2 in which models are divided into those developed (and validated) in primary care, and those developed (and validated) in secondary care.

At all selected risk thresholds the seven models developed in primary care populations achieved high specificity (range 0.90-0.98), whilst the sensitivity ranged from 0.25 for the QCancer (colon) model [25] with the threshold set at the top $1 \%$ in internal validation, to 1.00 for the Fijten et al. model developed from a cohort of patients presenting to primary care practices in the Netherlands with rectal bleeding that contained only nine CRC cases [21]. Information on sensitivity and specificity of three models developed in primary care was reported in external cohorts: the CAPER score [24] and the two QCancer ${ }^{\circ}$ (colon) models for male and female individuals [33]. Whilst all three models had similarly high specificity, the QCancer ${ }^{\circ}$ (colon) models had higher sensitivity at all thresholds used for external validation and performed better in males then females.

Only one model developed in secondary care, the Weighted numerical scoring system (WNS) [30], has been externally validated. Four studies reported the sensitivity and specificity at four different thresholds (a score of 40, 50,60 or 70). As expected, the lowest threshold of 40 had the highest pooled sensitivity (0.96 (95 \% C.I. 0.93-0.97), $n=4$ studies $)$ and the lowest pooled specificity $(0.40$ (95\% C.I. 0.39-0.41), $n=4$ studies), whilst the threshold of 70 had values comparable to those in primary care with a lower sensitivity of 0.64 (95\% C.I. $0.53-0.74)(n=3)$ and higher specificity of 0.82 (95\% C.I. $0.81-0.83)(n=3)$.

\section{Discrimination}

The discriminatory performance of 11 of the 16 models was reported as the AUROC. As shown in Fig. 3, these range from 0.83 to 0.97 in model development populations, 0.89 to 0.91 in internal validation studies, and 0.76 to 0.92 in external validation studies. The highest discriminatory performance (AUROC 0.97) was achieved by the model developed by Fijten et al. in patients presenting to primary care practices in the Netherlands with rectal bleeding [21]. However, in an external validation study of the model in secondary care the discrimination fell to 0.78 [34]. The models demonstrating the best discrimination in external validation studies were the $\mathrm{BB}$ equation developed by Marshall et al. using a case-control design in the The Health Improvement Network (THIN) database of English primary care records [24] and the QCancer ${ }^{\circ}$ (colon) male and female models developed from a cohort within the QResearch database of English primary care records [25].

\section{Other performance measures and utility}

Three models reported performance as positive predictive values (PPVs): the model by Lam et al. with a combined outcome of CRC or a polyp measuring $1 \mathrm{~cm}$ or bigger or any size with a villous histology derived in Hong Kong from a secondary care population in which PPVs ranged from 4.5 to $33.6 \%$ [20], and the models developed by Hamilton et al. in the UK from primary care populations with PPVs ranging from 0.42 to $11 \%$ [22], and from 0.04 to $4.5 \%$ [23].

No studies reported numerical measures of calibration but Hippisley-Cox et al. 2012 showed plots of observed and predicted risk for the male and female QCancer ${ }^{\circ}$ (colon) models in internal validation and these show overall good calibration [25].

Only one study assessed the utility of a risk model in practice: the risk score developed by Hamilton et al. 2009 [23] was assessed alongside a risk score for lung cancer in 165 UK general practices [19]. Paper, mousemat and desktop easel forms displaying the risk models were provided for a six month period. During this time there was an increase in cancer diagnostic activity, urgent referrals and cancer diagnoses when compared with the previous six months but as it was not a trial it is not possible to say whether these changes were due to the use of the risk model. 
Table 2 Variables included in risk models and TRIPOD classification of studies examining model performance

\begin{tabular}{|c|c|c|c|c|c|c|c|c|c|c|c|c|c|}
\hline \multirow[t]{2}{*}{ Author, year } & \multirow{2}{*}{$\begin{array}{l}\text { TRIPOD } \\
\text { level }^{\mathrm{a}}\end{array}$} & \multicolumn{5}{|c|}{ Demographic variables } & \multicolumn{2}{|c|}{ Personal and Family Medical History } & \multicolumn{5}{|c|}{ Symptoms } \\
\hline & & Age & Sex & Smoking & Alcohol & Other & $\begin{array}{l}\text { Family history } \\
\text { of Gl cancer }\end{array}$ & Other & $\begin{array}{l}\text { Rectal } \\
\text { bleeding }\end{array}$ & $\begin{array}{l}\text { Change in } \\
\text { bowel habit }\end{array}$ & Diarrhoea & Constipation & $\begin{array}{l}\text { Abdominal } \\
\text { pain }\end{array}$ \\
\hline \multicolumn{14}{|c|}{ Models predicting gastrointestinal cancers and neoplasms } \\
\hline Adelstein, 2010 [32] & $1 b$ & $\bullet$ & $\bullet$ & & & & & $\begin{array}{l}\text { Colonoscopy in last } 10 \text { years; } \\
\text { history of diverticular disease, } \\
\text { NSAID use, or aspirin use. }\end{array}$ & $\bullet$ & & & & $\bullet$ \\
\hline Adelstein, 2011 [31] & $1 \mathrm{a}$ & $\bullet$ & $\bullet$ & $\bullet$ & & Education level. & & $\begin{array}{l}\text { Colonoscopy in last } 10 \text { years; } \\
\text { history of colorectal polyps, } \\
\text { IBS, NSAID use or aspirin use. }\end{array}$ & $\bullet$ & & & & \\
\hline Fijten, 1995 [21] & $1 \mathrm{a}, 4$ & $\bullet$ & & & & & & & $\bullet^{d}$ & $\bullet$ & & & \\
\hline Hamilton, 2005 [22] & $1 a$ & & & & & & & & $\bullet$ & & $\bullet$ & & $\bullet$ \\
\hline Hamilton, 2009 [23] & $1 \mathrm{a}$ & & & & & & & & $\bullet$ & $\bullet$ & $\bullet$ & $\bullet$ & $\bullet$ \\
\hline Hippisley-Cox, 2012 (Male) [25] & $2 a, 4$ & $\bullet$ & $\begin{array}{l}\text { N/ } \\
\text { A }\end{array}$ & & $\bullet$ & & $\bullet$ & & $\bullet$ & $\bullet$ & & & $\bullet$ \\
\hline Hippisley-Cox, 2012 (Female) [25] & $2 \mathrm{a}, 4$ & $\bullet$ & $\begin{array}{l}\mathrm{N} / \\
\mathrm{A}\end{array}$ & & & & $\bullet$ & & $\bullet$ & & & & $\bullet$ \\
\hline Hurst, 2007 [28] & $1 a$ & $\bullet$ & $\bullet$ & $\bullet$ & & & & & & & & & $\bullet$ \\
\hline Lam, 2002 [20] & $1 \mathrm{a}$ & $\bullet$ & & & & & & & $\bullet$ & & & & \\
\hline Mahadavan, 2011 [29] & $1 a$ & $\bullet$ & $\bullet$ & & & & & & $\bullet$ & & & & \\
\hline Marshall, 2011 (BB equation) [24] & 3 & & & & & & & & $\bullet$ & $\bullet$ & $\bullet^{f}$ & $\bullet^{f}$ & $\bullet^{f}$ \\
\hline Marshall, 2011 (CAPER score) [24] & 4 & & & & & & & & & & $\bullet$ & $\bullet$ & $\bullet$ \\
\hline Selvachandran, 2002 (WNS) [30] ${ }^{c}$ & $\begin{array}{l}4,4,4 \\
4\end{array}$ & $\bullet$ & $\bullet$ & & & & & $\begin{array}{l}\text { 'Family history', 'relevant } \\
\text { medical history'. }\end{array}$ & $\bullet$ & • & & & \\
\hline \multicolumn{14}{|c|}{ Models predicting cancers of multiple organ systems alongside colorectal cancer } \\
\hline Hippisley-Cox, 2013 (Male) [27] & $2 a$ & $\bullet$ & $\begin{array}{l}\mathrm{N} / \\
\mathrm{A}\end{array}$ & • & $\bullet$ & $\begin{array}{l}\text { BMl; Townsend } \\
\text { deprivation score. }\end{array}$ & • & $\begin{array}{l}\text { History of chronic pancreatitis, } \\
\text { type } 2 \text { diabetes, or COPD; } \\
\text { family history of prostate cancer. }\end{array}$ & $\bullet$ & $\bullet$ & & $\bullet$ & $\bullet$ \\
\hline Hippisley-Cox, 2013 (Female) [26] & $2 a$ & $\bullet$ & $\begin{array}{l}\mathrm{N} / \\
\mathrm{A}\end{array}$ & • & $\bullet$ & $\begin{array}{l}\text { BMl; Townsend } \\
\text { deprivation score. }\end{array}$ & • & $\begin{array}{l}\text { History of chronic pancreatitis, } \\
\text { type } 2 \text { diabetes, COPD, or } \\
\text { endometrial hyperplasia/polyps; } \\
\text { family history of breast cancer } \\
\text { or ovarian cancer. }\end{array}$ & $\bullet$ & $\bullet$ & & $\bullet$ & $\bullet$ \\
\hline
\end{tabular}


Table 2 Variables included in risk models and TRIPOD classification of studies examining model performance (Continued)

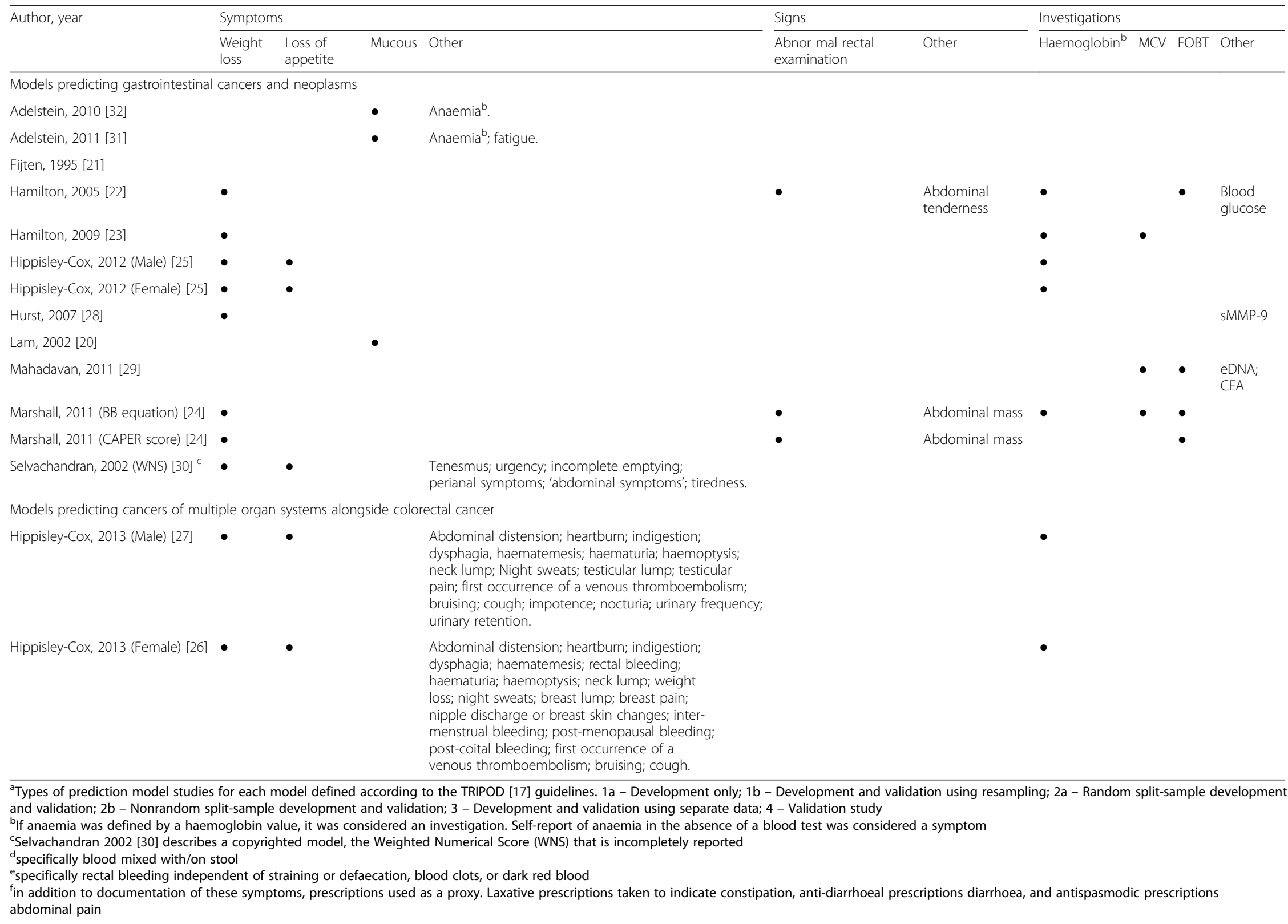




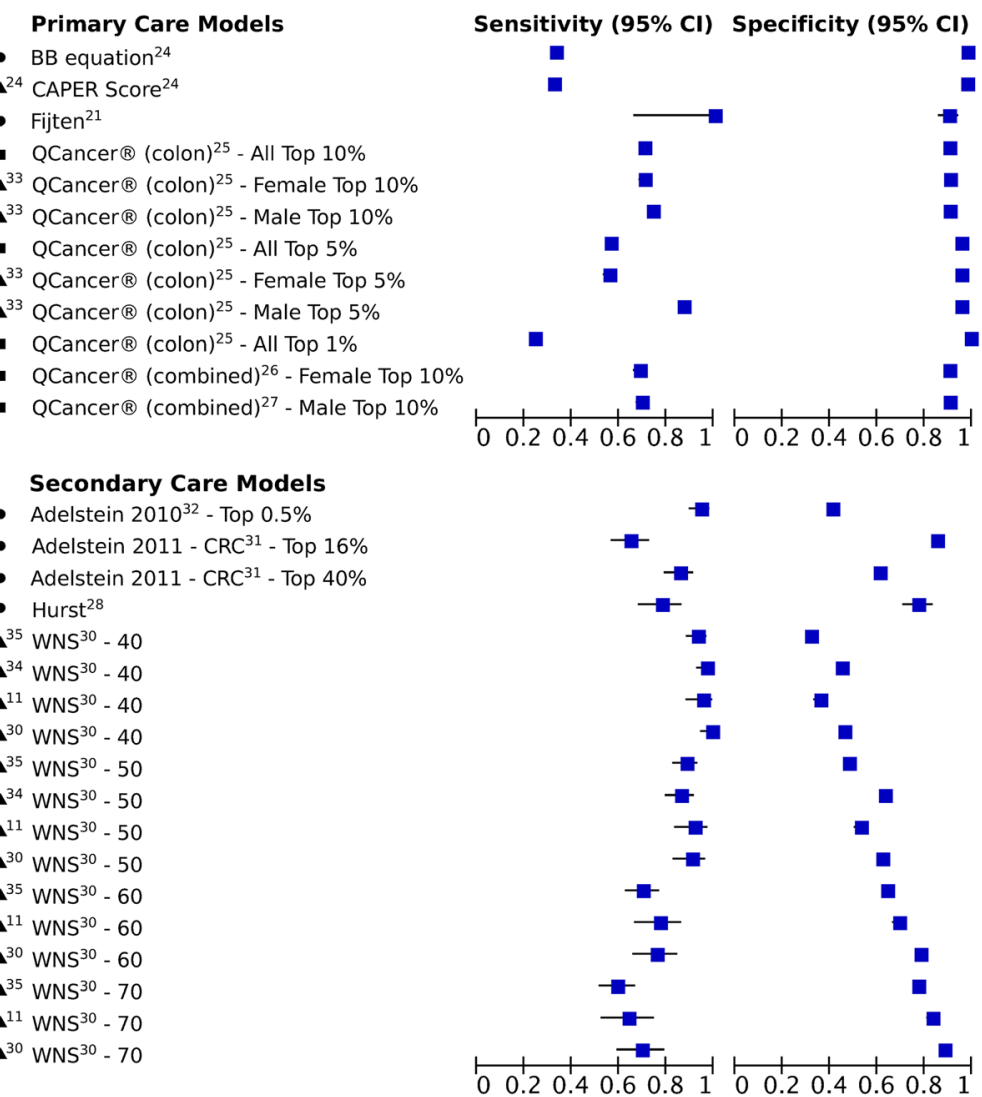

Fig. 2 Sensitivities and specificities of risk prediction models at reported thresholds. $\bullet$ indicates performance in a development population, $\mathbf{a}$ in an internal validation, and black triangle in an external validation (referenced). CRC - colorectal cancer. WNS - weighted numerical score

\section{Comparison with existing guidelines}

Although the aim of this review was not to assess the performance of referral guidelines for CRC, five papers [11, $24,30,34,35]$ simultaneously compared the performance of risk models with that of published guidelines.

Four compared the sensitivity and specificity of the WNS to UK national or regional guidelines (Fig. 4): in three $[11,30,34]$ a threshold of 50 or 60 in the WNS had a higher sensitivity and specificity than the guidelines, and in the fourth [35] a threshold of 60 had similar performance to both the NICE consultation guidelines published in 2004 [36] and the 2000 Department of Health [37] guidelines.

Figure 4 also shows Marshall et al.'s [24] study which compared the BB equation and CAPER score to three variations of NICE guidance in the UK THIN primary care database. They found the sensitivity and specificity of both risk models to be similar to the NICE 2005 guidelines [38]; however the authors also report the discrimination and show that both models outperformed the NICE guidelines with AUROCs of 0.83 (BB Equation) and 0.79 (CAPER Score), compared to 0.65 for the best performing interpretation of NICE guidelines. The same study [24] also compared the discrimination of the BB equation, CAPER score and NICE guidelines in a primary care case-control study with participants recruited from 21 practices in the UK. Again, the AUROCs achieved by the BB Equation (0.92) and CAPER Score (0.91) were significantly higher than the best performing interpretation of NICE guidelines (0.76).

\section{Discussion}

\section{Strengths and weaknesses}

The main strengths of this review are the broad search strategy and the systematic approaches used to identify studies and extract data. However, as with all systematic reviews, our conclusions are limited by the quality of published research. The included studies were heterogeneous in design, setting and duration of follow-up. Additionally, although we only included risk models with published performance data, two only provided positive predictive values, only six have been validated in external populations, and only one has been assessed for clinical utility or impact. This tendency for research into risk prediction tools to focus on model development rather than validation and impact is well documented $[39,40]$. Nevertheless, it limits the conclusions that can be made about the potential role of these risk models in clinical practice. 


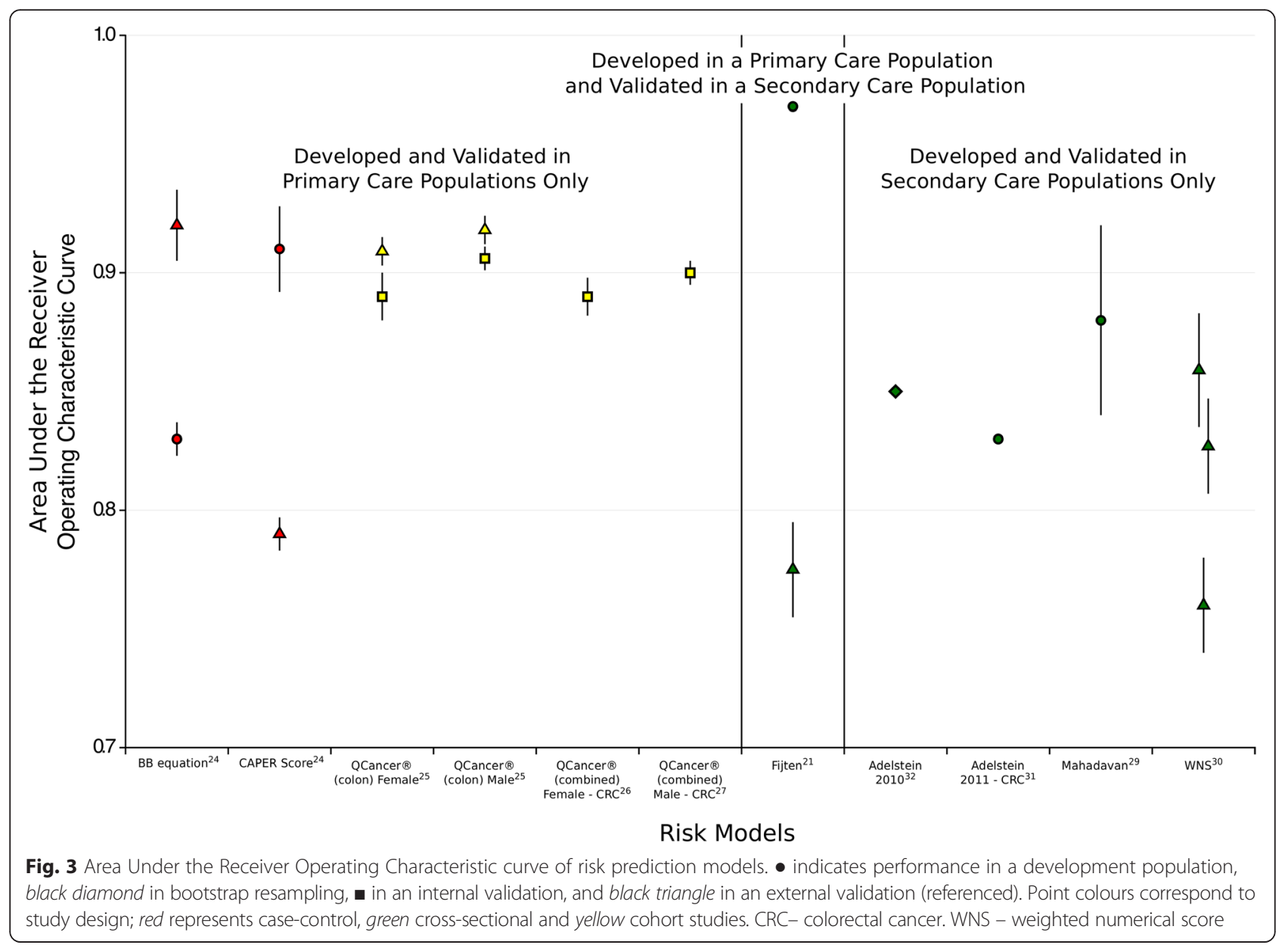

\section{Comparison between risk models}

Where data on discrimination and accuracy was reported there is little to distinguish between the models developed and validated in primary care. The four QCancer ${ }^{\ominus}$ models [25-27] were developed and validated using prospective cohort designs within two large UK primary care record databases, QResearch (development) and THIN (validation). All contain a combination of demographic, symptom, and investigation variables routinely recorded in electronic medical records, and all have AUROCs above 0.89 in either split-sample or external validation, and sensitivities around 0.7 with specificities over 0.95. The BB equation was also developed in the THIN database but using a case-control design [24] and has been validated in a dataset of paperbased primary care records from 21 English primary care practices, whilst the CAPER score was developed from those same primary care records and validated in the THIN database [24]. Both the BB equation and CAPER score performed better in the primary care record dataset, achieving comparable AUROCs and sensitivity and specificity to the QCancer ${ }^{\circledR}$ models. As Marshall et al. [24] describe, reasons for this may include the fact that clinical features of colorectal cancer were identified from both paper and electronic records and included analysis of free text in the primary care record dataset. The use of case-control designs instead of cohort studies for both the development and validation of these risk models, however, means that these measures may not accurately reflect their performance in population based cohorts due to the wide dispersion of risk factors in the cases and controls and the restricted distribution of matched variables.

Additionally none of these models have been validated outside data routinely collected by General practitioners (GPs). It is known that some symptoms are more likely to be recorded by a GP in patients in whom cancer is suspected. For example, patients coded as having a change in bowel habit are at greater risk than those with diarrhoea or constipation [41]. As a result of this coding bias it is likely that the recorded symptoms used in these models overestimate the significance of those symptoms in the presenting population. Whilst all these models in primary care can therefore accurately discriminate between patients in whom GPs have or have not chosen to routinely record these symptoms and could be used to identify those 


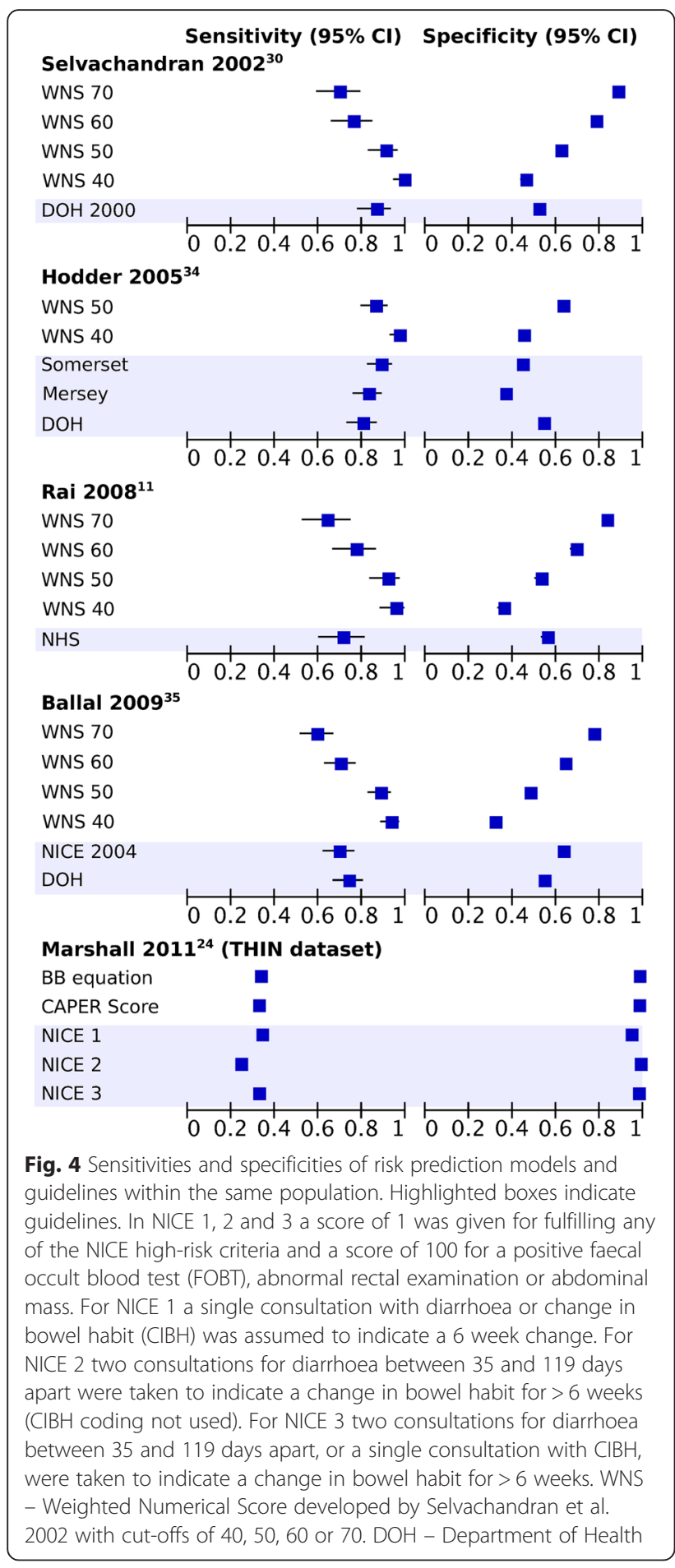

in whom further investigation or referral is necessary, how they perform in the consultation setting when GPs are having to decide whether the patient in front of them does or does not have a given symptom is not known.

Models developed and validated in secondary care settings were instead all based on cross-sectional studies of patients referred with symptoms of CRC with data collected using patient and/or physician questionnaires at the time of investigation. All have similar discrimination (AUROC 0.8 to 0.9 ) in development populations, but the only model to be externally validated is the WNS developed by Selvachandran et al. [30]. This has been validated in four separate populations with a prevalence of CRC of around $5 \%$. The AUROCs range from 0.76 [35] to 0.86 [30] and sensitivity and specificity from 0.96 and 0.40 to 0.64 and 0.82 . A low threshold, with a high sensitivity, could therefore be used to identify those in whom further investigation is not required. However, all the patients included in these studies had already been assessed as high risk by primary care physicians so the score would be likely to perform less well in an un-referred primary care population, therefore validation in that setting is required.

\section{Implications for clinicians and policy makers}

The risk models identified in this review have the potential to improve the diagnosis of CRC by helping clinicians to identify those patients presenting with symptoms of possible CRC in whom further investigation and referral is most appropriate. The potential advantages of risk prediction models in this context are that they can include combinations of symptoms and other risk factors, and different thresholds for action can be used. For example, a threshold with high sensitivity and high specificity could be used to define a high risk patients that require urgent referral, whilst one with very high sensitivity and low specificity could be used to identify those who do not require further investigation at that time.

Sackett and Haynes [42] identified four questions which must be addressed before incorporating diagnostic tests into clinical practice, however. The first three are concerned with test performance: whether test results are different between those with and without the condition; whether patients with certain test results are more likely to have the target disorder; and whether the test results distinguish patients with and without the target disorder. This review shows that risk models for CRC do exist which meet these criteria, with the best performing having sensitivities above 0.7 , specificities above 0.9 and AUROCs over 0.9 in external validation studies.

Most contain variables that are easily obtainable in a single consultation and so could relatively easily be incorporated into practice. Whether any of them are any better than a clinician's assessment is, however, uncertain. In the only study to compare a risk model with clinical judgement [30] the WNS was compared to the specialist clinical assessment of a comprehensive questionnaire-gathered history and there was no significant difference in discrimination. There is more evidence to suggest that the models are better than previous referral guidelines. Although not the primary aim of this review, in all cases where models were compared with guidelines the 
predictive models showed better discrimination and equal or better accuracy $[11,24,30,34,35]$.

\section{Unanswered questions and future research}

This review also cannot answer Sackett and Hayne's fourth question - whether patients undergoing the diagnostic test fare better than similar untested patients. No studies have sought to address that. Before incorporating any of these risk models into practice, further research is therefore needed to validate the most promising models in clinical settings in comparison to clinical judgement and current referral guidelines, and to assess the impact of the use of these risk models in practice. Further work is also needed to consider whether CRC alone or in combination with advanced colorectal neoplasia or adenoma is the most appropriate outcome. This review focused on risk prediction models for CRC and only two models, which both reported only limited performance data and have not been validated, included advanced colorectal neoplasia or adenoma in addition to CRC [20,28]. It is, therefore, not possible from this review alone to know how the performance of models predicting the combined outcome of advanced colorectal neoplasia and CRC compares to those with CRC as a single outcome. One study, however, reported the performance of risk models for CRC, advanced adenoma, or adenomas 6-9 $\mathrm{mm}$ in diameter separately within the same population [31]. The discrimination for the CRC model was substantially better (AUROC 0.87 compared to 0.70 and 0.67 for advanced adenoma and adenomas 6-9 $\mathrm{mm}$ in diameter respectively). This probably reflects the fact that many adenomas are asymptomatic and so identified less well by risk prediction models developed in symptomatic populations. The discriminatory performance for advanced adenoma in this symptomatic population is comparable with risk models developed for asymptomatic individuals [43]. This suggests that models with a combined outcome of advanced colorectal neoplasia and CRC may identify those with CRC less well than models with CRC as a single outcome. However, it is widely accepted that CRC arises from the adenomacarcinoma sequence and so identification of patients with advanced colorectal neoplasia has the potential to reduce future incidence of invasive CRC. The choice of outcome(s) therefore depends on the purpose for which the risk models are to be used. If the priority is identification of patients with prevalent $\mathrm{CRC}$, then a risk model including $\mathrm{CRC}$ as the sole outcome is likely to have the greatest discrimination and accuracy and allow targeting of referrals and further investigations most effectively. If the priority is instead to identify both prevalent CRC and those patients at high risk of developing CRC in the future, then a risk model including advanced colorectal neoplasia would be more appropriate.
The introduction of a two-step process into the recently updated NICE referral guidelines [44], in which the referral decision for individuals at intermediate risk is made based on the result of testing for occult blood in faeces, also provides an opportunity for research into incorporating other pre-referral tests into risk models. These include faecal immunochemical tests [16] and potentially more specialised tests, such as exfoliated DNA and carcinoembryonic antigen (CEA), which were of predictive value in secondary care developed models.

From work in other disease areas [45-49] we know that uncertainty about how to account for risk factors perceived to be important but not included in the tools, and the perception that clinical judgement is as good as or better than risk tools, contribute to the low uptake of risk models. Practical issues such as lack of time, poor knowledge or understanding of the tools, and poor computer software also restrict model use. Additionally, a recent study using simulated consultations with risk prediction tools for cancer has shown that clinicians may interpret symptoms inconsistently, leading to inaccurate and unreliable cancer risk assessment, and GPs were reluctant to use the tools for fear of alarming their patients if the risk information is presented too explicitly [50]. Research is therefore also needed to understand how best to incorporate risk prediction models into routine practice, including communication of risk information to patients, and to address the barriers to their use.

\section{Conclusions}

To our knowledge this is the first systematic review of risk prediction models for CRC in symptomatic populations. We have shown that 15 models have been developed across both primary and secondary care populations. Many of these have good discrimination (AUROC $>0.85$ ) and most contain variables that are easily obtainable in a single consultation. However, only six have been validated in external populations, and only one model has been assessed for clinical utility in a single before and after study with no control group. Further research is therefore needed before they can be incorporated into routine clinical practice.

\section{Additional files}

Additional file 1: PRISMA checklist, Completed PRISMA checklist (DOC $116 \mathrm{~kb}$ )

Additional file 2: Search strategies, Full details of search strategies used for Medline and EMBASE. (DOCX $24 \mathrm{~kb}$ )

\section{Abbreviations}

2WW, Two-week wait referral system; AUROC, Area under the receiver operating characteristic curve; BB equation, The Bristol-Birmingham equation; CEA, Carcinoembryonic antigen; $\mathrm{ClBH}$, Change in bowel habit; CRC, Colorectal cancer; DOH, Department of Health; FOBT, Faecal occult blood test; GP, General practitioner; $\mathrm{Hb}$, Haemoglobin; IBD, Inflammatory bowel disease; NICE, National Institute for Clinical Excellence; ONS, Office of National Statistics; PPV, Positive 
predictive value; THIN, The Health Improvement Network; WNS, Weighted numerical scoring system

\section{Acknowledgements}

We thank Isla Kuhn, Reader Services Librarian, University of Cambridge Medical Library, for her help developing the search strategy.

\section{Funding}

JUS is funded by a National Institute of Health Research (NIHR) Clinical Lectureship and FMW by an NIHR Clinician Scientist award. JC has received a twinning grant for a stay in the University of Cambridge through the European Commission supported "BIOCAPS" project (FP-7-REGPOT 20122013-1, Grant agreement no. FP7- 316265). The views expressed in this publication are those of the authors and not necessarily those of the NHS, the NIHR or the Department of Health. All researchers were independent of the funding body and the study sponsors and funder had no role in study design; data collection, analysis and interpretation of data; in the writing of the report; or decision to submit the article for publication.

\section{Availability of data and materials}

All data are available from the reports or authors of the primary research. No additional data is available.

\section{Authors' contributions}

All authors were involved in the design of the study. TGSW screened papers for inclusion, extracted data, analysed the results and jointly drafted the first version of the manuscript. JUS performed the initial search, screened the papers for inclusion, reviewed extracted data, analysed the results and jointly drafted the first version of the manuscript. JC extracted data, analysed the results and critically revised the manuscript, and FMW and SG analysed the results and critically revised the manuscript. JUS is guarantor for the study. All authors read and approved the final manuscript.

\section{Competing interests}

All authors have completed the Unified Competing Interest form at http:// www.icmje.org/conflicts-of-interest/ (available on request from the corresponding author) and declare that (1) they have no support from or relationships with companies that might have an interest in the submitted work in the previous 3 years; (2) their spouses, partners, or children have no financial relationships that may be relevant to the submitted work; and (3) they have no non-financial interests that may be relevant to the submitted work.

\section{Consent for publication}

Not applicable.

\section{Ethical approval and consent to participate}

As this research did not include primary data collection no ethical approval was required.

\section{Author details}

${ }^{1}$ School of Clinical Medicine, University of Cambridge, Cambridge, UK. ${ }^{2}$ Department of Gastroenterology, Complexo Hospitalario Universitario de Ourense, Instituto de Investigación Biomédica Ourense-Vigo-Pontevedra, Ourense, Spain. ${ }^{3}$ The Primary Care Unit, Department of Public Health and Primary Care, University of Cambridge, Cambridge CB1 8RN, UK.

Received: 23 October 2015 Accepted: 27 May 2016

\section{Published online: 13 June 2016}

\section{References}

1. Ferlay J, Soerjomataram II, Dikshit R, Eser S, Mathers C, Rebelo M, et al. Cancer incidence and mortality worldwide: sources, methods and major patterns in GLOBOCAN 2012. Int J Cancer. 2014;136:E359-86.

2. Cancer Research UK. By stage at diagnosis. London: Cancer Research UK; 2009. Available from: http://www.cancerresearchuk.org/health-professional/cancerstatistics/statistics-by-cancer-type/bowel-cancer/survival\#heading-Three.

3. Garborg K, Holme Ø, Løberg M, Kalager M, Adami HO, Bretthauer M. Current status of screening for colorectal cancer. Ann Oncol. 2013;24:1963-72.

4. Cotterchio M, Manno M, Klar N, McLaughlin J, Gallinger S. Colorectal screening is associated with reduced colorectal cancer risk: A case-control study within the population-based ontario familial colorectal cancer registry. Cancer Causes Control. 2005;16:865-75.

5. Edwards BK, Ward E, Kohler BA, Eheman C, Zauber AG, Anderson RN, et al. Annual report to the nation on the status of cancer, 1975-2006, featuring colorectal cancer trends and impact of interventions (risk factors, screening, and treatment) to reduce future rates. Cancer. 2010;116(3): 544-73. doi:10.1002/cncr.24760.

6. Mansouri D, McMillan DC, Crearie C, Morrison DS, Crighton EM, Horgan PG. Temporal trends in mode, site and stage of presentation with the introduction of colorectal cancer screening: a decade of experience from the West of Scotland. Cancer: Br. J; 2015.

7. Ford AC, Veldhuyzen van Zanten SJO, Rodgers CC, Talley NJ, Vakil NB, Moayyedi P. Diagnostic utility of alarm features for colorectal cancer: systematic review and meta-analysis. Gut. 2008;57:1545-53.

8. Astin M, Griffin T, Neal RD, Rose P, Hamilton W. The diagnostic value of symptoms for colorectal cancer in primary care. Br J Gen Pract. 2011;61(586):e231-43.

9. Jellema $P$, van der Windt DAWM, Bruinvels DJ, Mallen CD, van Weyenberg $\mathrm{SJB}$, Mulder CJ, et al. Value of symptoms and additional diagnostic tests for colorectal cancer in primary care: systematic review and meta-analysis. BMJ. 2010;340:c1269. doi:10.1136/bmj.c1269.

10. National Institute for Health and Care Excellence. NICE Guidelines [NG12] Suspected cancer: recognition and referral [Internet]. Available from: https://www.nice.org.uk/guidance/ng12. Accessed 28 Aug 2015.

11. Rai S, Ballal M, Thomas WM, Miller AS, Jameson JS, Steward WP. Assessment of a patient consultation questionnaire-based scoring system for stratification of outpatient risk of colorectal cancer. Br J Surg. 2008;95:369-74.

12. Chohan DPK, Goodwin K, Wilkinson S, Miller R, Hall NR. How has the "twoweek wait" rule affected the presentation of colorectal cancer? Colorectal Dis. 2005;7:450-3.

13. Thorne K, Hutchings HA, Elwyn G. The effects of the Two-Week Rule on NHS colorectal cancer diagnostic services: a systematic literature review. BMC Health Serv Res. 2006;6:43.

14. Shabbir J, Vijayan V, Silavant M, Fowler AL, Cook TA, Lucarotti ME. Two week rule referral for patients with colorectal cancer below the age of 50; Are we being ageist? Surg. 2009;7:276-81. Royal College of Surgeons of Edinburgh and Royal College of Surgeons in Ireland.

15. Zafar A, Mak T, Whinnie S, Chapman MAS. The 2-week wait referral system does not improve 5-year colorectal cancer survival. Colorectal Dis. 2012;14:e177-80

16. Cubiella J, Salve M, Díaz-Ondina M, Vega P, Alves MT, Iglesias F, et al. Diagnostic accuracy of faecal immunochemical test for colorectal cancer in symptomatic patients: comparison with NICE and SIGN referral criteria. Colorectal Dis. 2014

17. Collins GS, Reitsma JB, Altman DG, Moons KGM. Transparent Reporting of a multivariable prediction model for Individual Prognosis Or Diagnosis (TRIPOD): The TRIPOD Statement. Ann Intern Med. 2015;162:55-63.

18. Critical Appraisal Skills Programme. Available from http://www.casp-uk.net/ \#!casp-tools-checklists/c18f8

19. Hamilton W, Green T, Martins T, Elliott K, Rubin G, Macleod U. Evaluation of risk assessment tools for suspected cancer in general practice: a cohort study. Br J Gen Pract. 2013;63:e30-6.

20. Lam DTY, Choy CLY, Lam SCW, Kwok SPY. Age and symptoms as a triage method for per-rectal bleeding. Ann Coll Surg Hong Kong. 2002;6:77-82.

21. Fijten GH, Starmans R, Muris JW, Schouten HJ, Blijham GH, Knottnerus JA. Predictive value of signs and symptoms for colorectal cancer in patients with rectal bleeding in general practice. Fam Pract. 1995;12:279-86.

22. Hamilton W, Round A, Sharp D, Peters TJ. Clinical features of colorectal cancer before diagnosis: a population-based case-control study. Br J Cancer. 2005:93:399-405.

23. Hamilton W, Lancashire R, Sharp D, Peters TJ, Cheng K, Marshall T. The risk of colorectal cancer with symptoms at different ages and between the sexes: a case-control study. BMC Med. 2009;7:17.

24. Marshall T, Lancashire R, Sharp D, Peters TJ, Cheng KK, Hamilton W. The diagnostic performance of scoring systems to identify symptomatic colorectal cancer compared to current referral guidance. Gut. 2011;60:1242-8.

25. Hippisley-Cox J, Coupland C. Identifying patients with suspected colorectal cancer in primary care: Derivation and validation of an algorithm. Br J Gen Pract. 2012;62:29-37.

26. Hippisley-Cox J, Coupland C. Symptoms and risk factors to identify women with suspected cancer in primary care: derivation and validation of an algorithm. Br J Gen Pract. 2013;63:e11-21. 
27. Hippisley-Cox J, Coupland C. Symptoms and risk factors to identify men with suspected cancer in primary care: derivation and validation of an algorithm. Br J Gen Pract. 2013;63:e1-10.

28. Hurst NG, Stocken DD, Wilson S, Keh C, Wakelam MJO, Ismail T. Elevated serum matrix metalloproteinase 9 (MMP-9) concentration predicts the presence of colorectal neoplasia in symptomatic patients. Br J Cancer. 2007;97:971-7.

29. Mahadavan L, Loktionov A, Daniels IR, Shore A, Cotter D, Llewelyn AH, et al. Exfoliated colonocyte DNA levels and clinical features in the diagnosis of colorectal cancer: a cohort study in patients referred for investigation. Colorectal Dis. 2012;14:306-13.

30. Selvachandran SN, Hodder RJ, Ballal MS, Jones P, Cade D. Prediction of colorectal cancer by a patient consultation questionnaire and scoring system: A prospective study. Lancet. 2002;360:278-83.

31. Adelstein B-A, Macaskill P, Turner RM, Katelaris PH, Irwig L. The value of age and medical history for predicting colorectal cancer and adenomas in people referred for colonoscopy. BMC Gastroenterol. 2011;11:97.

32. Adelstein BA, Irwig L, MacAskill P, Turner RM, Chan SF, Katelaris PH. Who needs colonoscopy to identify colorectal cancer? Bowel symptoms do not add substantially to age and other medical history. Aliment Pharmacol Ther. 2010;32:270-81.

33. Collins GS, Altman DG. Identifying patients with undetected colorectal cancer: an independent validation of QCancer (Colorectal). Br J Cancer. 2012;107:260-5.

34. Hodder RJ, Ballal M, Selvachandran SN, Cade D. Pitfalls in the construction of cancer guidelines demonstrated by the analysis of colorectal referrals. Ann R Coll Surg Engl. 2005;87:419-26.

35. Ballal MS, Selvachandran SN, Maw A. Use of a patient consultation questionnaire and weighted numerical scoring system for the prediction of colorectal cancer and other colorectal pathology in symptomatic patients: A prospective cohort validation study of a Welsh population. Color Dis. 2010;12:407-14

36. National Institute for Health and Care Excellence. Referral guidelines for suspected cancer, Draft for first consultation. 2004.

37. Department of Health. Referral Guidelines for Suspected Colorectal Cancer. NHS Exec. Heal. Serv. Circ. 2000;19.

38. National Institute for Health and Care Excellence. Referral guidelines for suspected cancer (CG27). 2005.

39. Moons KGM, Kengne AP, Grobbee DE, Royston P, Vergouwe Y, Altman DG, et al. Risk prediction models: II. External validation, model updating, and impact assessment. Heart. 2012;98:691-8.

40. Toll DB, Janssen KJM, Vergouwe Y, Moons KGM. Validation, updating and impact of clinical prediction rules: a review. J Clin Epidemiol. 2008;61:1085-94.

41. Jones R, Latinovic R, Charlton J, Gulliford MC. Alarm symptoms in early diagnosis of cancer in primary care: cohort study using General Practice Research Database. BMJ. 2007;334:1040.

42. Sackett DL, Haynes RB. The architecture of diagnostic research. BMJ. 2002; 324:539-41.

43. Usher-Smith JA, Walter FM, Emery J, Win AK, Griffin SJ. Risk prediction models for colorectal cancer: a systematic review. Cancer Prev Res (Phila). 2015:9(1):13-26. doi:10.1158/1940-6207.

44. National Institute for Health and Care Excellence. Suspected cancer: recognition and referral (NG12). 2015.

45. Van Steenkiste B, Van Der Weijden T, Stoffers HEJH, Grol R. Barriers to implementing cardiovascular risk tables in routine general practice. Scand J Prim Health Care. 2004;22:32-7.

46. Bonner C, Jansen J, MCKinn S, Irwig L, Doust J, Glasziou P, et al. General practitioners' use of different cardiovascular risk assessment strategies: a qualitative study. Med J Aust. 2013;199:485-9.

47. Torley D, Zwar N, Comino EJ, Harris M. GPs' views of absolute cardiovascular risk and its role in primary prevention. Aust Fam Physician. 2005;34:503-4. 507.

48. Müller-Riemenschneider F, Holmberg C, Rieckmann N, Kliems H, Rufer V, Müller-Nordhorn J, et al. Barriers to routine risk-score use for healthy primary care patients: survey and qualitative study. Arch Intern Med. 2010;170:719-24.

49. Schmieder RE, Goebel M, Bramlage P. Barriers to cardiovascular risk prevention and management in Germany-an analysis of the EURIKA study. Vasc Health Risk Manag. 2012;8:177-86.

50. Chiang PPC, Glance D, Walker J, Walter FM, Emery JD. Implementing a QCancer risk tool into general practice consultations: an exploratory study using simulated consultations with Australian general practitioners. Br J Cancer. 2015;112:1-7.

\section{Submit your next manuscript to BioMed Central and we will help you at every step:}

- We accept pre-submission inquiries

- Our selector tool helps you to find the most relevant journal

- We provide round the clock customer support

- Convenient online submission

- Thorough peer review

- Inclusion in PubMed and all major indexing services

- Maximum visibility for your research

Submit your manuscript at www.biomedcentral.com/submit
Biomed Central 